The anipersity of Cbicago

REMOTE STORACE

\title{
SUCCESSIONS OF VEGETATION IN BOULDER PARK, COLORADO
}

\author{
A DISSERTATION \\ SUBMITTED TO THE FACULTY \\ OF THE OGDEN GRADUATE SCHOOL OF SCIENCE \\ IN CANDIDACY FOR THE DEGREE OF \\ DOCTOR OF PHILOSOPHY \\ DEPARTMENT OF BOTANY \\ BY \\ WILFRED WILLIAM ROBBINS
}

Private Edition, Distributed By

THE UNIVERSITY OF CHICAGO LIBRARIES

CHICAGO, ILLINOIS

Reprinted from

The Botanical Gazette, Vol. LXV, No. 6

June, IgI 8 
X.6. $3: 4: 1$

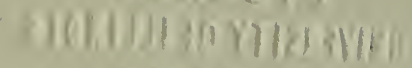

a.s.s.be in

- 


\title{
The Unipersity of Chicago
}

\section{SUCCESSIONS OF VEGETATION IN BOULDER PARK, COLORADO}

\author{
A DISSERTATION \\ SUBMITTED TO THE FACULTY \\ OF THE OGDEN GRADUATE SCHOOL OF SCIENCE \\ IN CANDIDACY FOR THE DEGREE OF \\ DOCTOR OF PHILOSOPHY \\ DEPARTMENT OF BOTANY
}

BY

WILFRED WILLIAM ROBBINS

Private Edition, Distributed By

THE UNIVERSITY OF CHICAGO LIBRARIES

CHICAGO, ILLINOIS

Reprinted from

The Botanical Gazette, Vol. LXV, No. 6

June, I9r 8 
Digitized by the Internet Archive in 2017 with funding from

University of Illinois Urbana-Champaign Alternates

https://archive.org/details/successionsofveg00robb 


\title{
Botanical Gazette
}

\author{
JUNE IOIS
}

\section{SUCCESSIONS OF VEGETATION IN BOULDER PARK, COLORADO}

CONTRIBUTIONS FROM THE HULL BOTANICAL LABORATORY 238

W. W. Rов в IN

(WITH FOURTEEN FIGURES)

\section{Introduction}

This paper is concerned chiefly with the plant successions of the flood plains, lakes, and ponds of a mountain park. They culminate in a temporary meadow climax. Consideration is also given to the succession which begins on the xerophytic glacial gravels and passes through the characteristic and long persistent "dry grassland" stage also to a temporary meadow climax. There is also presented the interesting problem of the genetic relation of the meadow to the forests of aspen, lodgepole pine, and Engelmann spruce-balsam fir which border the open park. It should be stated that Boulder Park is typical, in its physiographic and vegetative development, of hundreds of such areas in the Rocky Mountain region.

Boulder Park is located in Gilpin County, Colorado, about 34 miles, in a straight line, west of Denver. The Divide of the main range of the Rocky Mountains is about 6 miles west; the Great Plains are about i 8 miles east. Tolland, a small town near the middle of the Park, has an altitude of 8889 feet. The area falls within the montane zone (Io). 
Boulder Park was selected as the site for the University of Colorado Mountain Laboratory, the first session being held in the summer of I909. Several papers (II, I2, I9) have been issued setting forth the facilities for field study at the Laboratory, but also presenting certain botanical features of the neighboring vegetation. Other papers dealing exclusively with the plant life of the Park and adjacent territory are referred to in this paper.

\section{Topography and physiographic history}

General.-The term "park" as used throughout the Rocky Mountain region refers to an open, flat, usually grassy area in the mountains. Such areas may be large, including Io० or more square miles; or small, containing only a portion of a square mile, and often possess a scattered growth of trees. Boulder Park is the broadened valley of South Boulder Creek. It is generally level, and through it flows the stream which is slowly working its way back and forth and producing well defined flood plains. The level portion of the park proper is bordered by steep slopes, the crests of which are 500-rooo ft. above the valley floor. The slopes have been burned over in large part, and exhibit various stages of the "burn succession," the most obvious of which are lodgepole pine and aspen. The climatic climax forest of Engelmann spruce-balsam fir is found in places. Some typical talus slopes occur. The country granitic rock is exposed in rugged outline in places, and may be observed in different stages of disintegration and decomposition, and in various stages of vegetative development. The building of the Moffat Railroad has created deep rock and gravel cuts, gravel and rock heaps and slides, often resembling talus and natural slides; likewise, the building of wagon roads has made many new areas whereupon secondary succession may be observed. The general topographic features of the Park may be seen by referring to figs. $\mathrm{I}-3$.

In Pleistocene times this area and many others in the mountains of Colorado were glaciated. The glaciers had their heads above timber line and moved down the valleys, leaving evidence of their action. The ice which was largely instrumental in shaping and modifying the topography of Boulder Park came from two sources, 



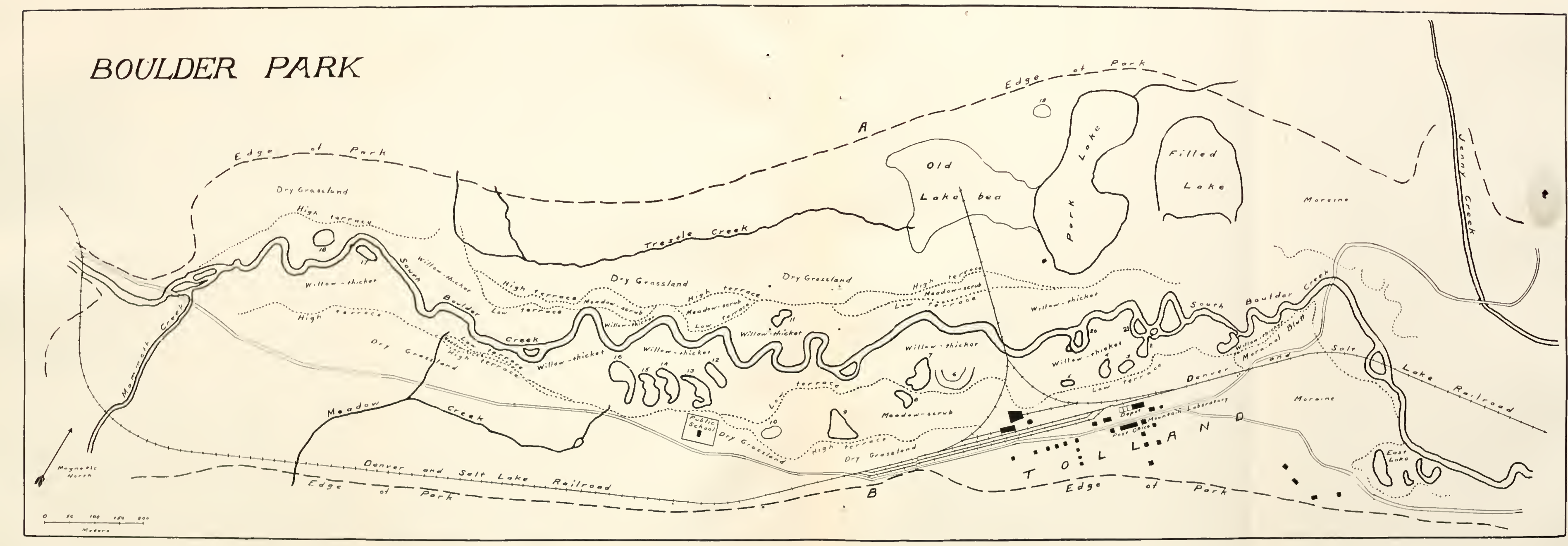


South Boulder Canyon and Mammoth Gulch. 'The two bodies of ice no doubt met at the upper end of the Park and filled it to a depth of $400-550 \mathrm{ft}$., as is evidenced by the elevation of perched boulders on both slopes bordering the Park. Below Tolland is an area of hummocky topography typically morainal. The hummocks and the depressions between are strewn with rounded boulders, so much weathered that all traces of glacial scratches are obliterated. Post-glacial stream action has washed away great quantities of this terminal moraine. Lateral moraines join with the terminal and extend up the valley on the sides of the ridges. There is also a very wide and deep morainal deposit at the mouth of Mammoth Gulch. A comparatively small amount of it has been carried away. At the entrance of South Boulder Canyon, however,

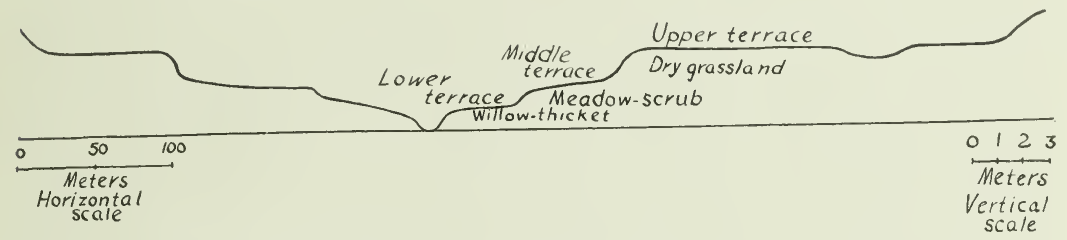

Fig. 2.-Profile of Boulder Park along line extending from $A$ to $B$ in fig. I

but small remnants of moraine remain. This is undoubtedly due to the fact that South Boulder is a much larger stream than Mammoth, and since the retreat of the glacier it has carried away almost all of its moraine.

It has just been indicated that there are two large distinct deposits of morainal material in the Park: one below Tolland, the other at the mouth of Mammoth Gulch. 'They probably represent the terminals of two distinct glacial bodies of ice belonging to different periods of glaciation. In all instances where investigations $(1,4,7,8,9,23,26)$ of the epochs of glaciation have been made in the western mountains, there have been two distinct epochs, and furthermore, in each case the earlier glacier extended farther than the later.

ORIGIN OF TERRACES.--The foregoing has been given in order to make clear the origin of the ponds and terraces which are such prominent features of the Park's topography. Figs. I and 2 show 
that there are 3 main levels bordering the stream: (I) Low terraces, into which the present stream is now cutting. During high waters a portion of this may be inundated. Gravel is overlaid with a deposit of peat, ranging in depth from an inch or so to 3 or $4 \mathrm{ft}$. This level is covered with a willow thicket association in which the dominant forms are Salix chlorophylla Anders. and

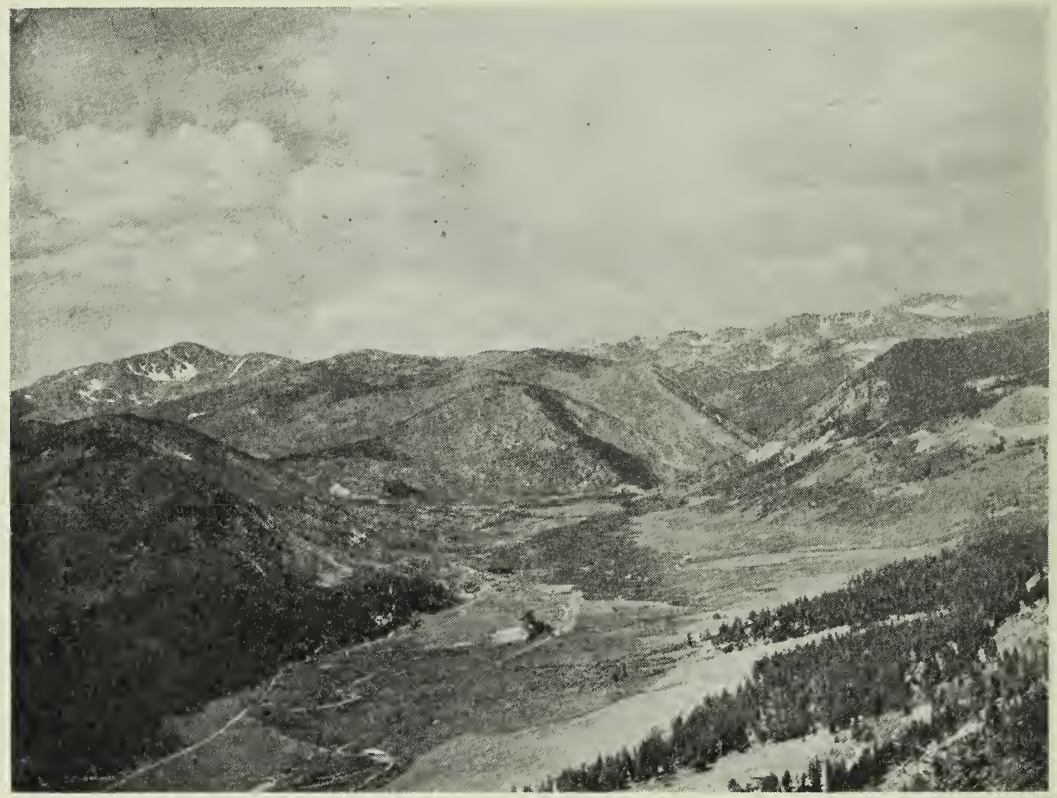

Fig. 3.-View of Boulder Park looking west: James Peak at left and Continental Divide in background; glimpses of stream may be seen flowing through willow thicket association; note lighter colored patches of dry grassland; slopes are clothed with aspen, lodgepole pine, and Engelmann spruce-subalpine fir.

S. padophylla Rydb. (2) Middle terraces, meander terraces much older than the preceding. On the middle level the gravel is not overlaid with peat, except in a few places. The soil is a sandy and gravelly loam and $4^{-8}$ inches deep. The characteristic vegetation is meadow scrub in which Salix glaucops Anders., Betula glandulosa Sarg., Dasiophora fruticosa (L.) Rydb., and mesophytic herbs are dominant. (3) High terraces, which are composed of glacial gravels which have been worked over by the stream which issued from the 
end of the retreating glacier. Typically, there is little accumulation of humus upon them. The vegetation is a "dry grassland."

The terminal moraine below Tolland undoubtedly acted as a dam to the stream coming from the glacial front, and for a long time the Park was the site of a lake. Subsequent to the period of deposition, the stream was lightened of its load and immediately began to cut into the terminal dam, which being of easily erorled material was quickly cut through. This resulted in a rapid drainage of the lake and the formation of a high terrace on each side of the stream issuing from the glacial front. The middle terraces are of stream origin.

Origin of LAKES AND PONDS. - With the exception of Park and Filled Lakes, all the natural ponds in the Park are of oxbow origin. Park and Filled Lakes are the largest and deepest. Their depth alone shows that they are not of oxbow origin. In the center of Filled Lake the peat is over ro ft. deep. At no other point in the Park is there such a deep peat deposit. The relation these two lakes bear to the higher level shows that they were not formed during the deposition of the material composing this level. On the retreat of the first glacier two large ice cores were left on the valley floor. Hence, when the wash from the later terminal was brought down the valley it was deposited about the edges of these débris covered bodies of ice. The ice melted later, leaving the two lakes, Park and Filled.

\section{Climatic factors}

There are no extended climatic records for Boulder Park. Robilns (22) has shown the following average temperature and precipitation relations to exist in the "lodgepole pine forest zone" of Colorado, and from these a notion may be gained of climatic conditions in Boulder Park.

Mean annual temperature.

Mean winter temperature $34.9^{\circ} \mathrm{F}$.

Mean spring temperature. $18.4^{\circ}$

Mean summer temperature. $33 \cdot 4^{\circ}$

Mean fall temperature. $53 \cdot 6^{\circ}$

Average length of frostless season $38 \cdot 4^{\circ}$

Average date of last spring frost

Average date of first fall frost.

June 20

Absolute annual range of temperature......... I04 days

Mean annual precipitation .............. 25.53 inches

Mean annual snowfall............... II 2.9 inches 
During a portion of the growing seasons of I9o9 and I9I3, thermographs were run by members of the staff of the Mountain Laboratory. They show that the daily range of temperature may run high. This is particularly the case during clear weather. The daily minimum temperature is usually reached between 5:00 and 6:00 A.M., the daily maximum between $\mathrm{I}: 00$ and 2:00 P.M. In I909 the latest freezing temperature was June 22; in I9I3 the temperature sometimes went down to freezing or below throughout July, and on August I of that year the minimum was $32^{\circ} \mathrm{F}$. Afternoon showers of short duration during June, July, and August are common. Prolonged rains are infrequent. Although there is considerable snow, its accumulation on the high terraces, particularly, is largely prevented by their exposure to the sweep of winds from the west. There are large drifts of snow, however, in protected situations.

Ramaley and Mitchell (18) in I909 determined the relative humidity at a number of Park stations. It varied on July 8 from 39 per cent on the north exposure of a railroad cut to 65 per cent in the lodgepole pine forest; on July $\mathrm{I} 2$, from 39 per cent in the railroad cut to $7 \mathrm{I}$ per cent in the forest.

\section{Successions}

\section{FLOOD PLAIN SUCCESSION}

Boulder Creek is a meandering stream with considerable cutting power. Along its course in the Park one may find shores of erosion, of deposition, and numerous oxbows in all physiographic and vegetative stages, and also well defined stream terraces. Hence there is an unexcelled opportunity here, as may be judged somewhat from a reference to fig. I, to study succession on a mountain flood plain.

Two types of embryonic flood plains occur along Boulder Creek in its course through the Park: (I) those composed of well rounded boulders (cobblestones), averaging 2-6 inches in diameter, with a slight admixture of coarse gravel (fig. 4); and (2) those made of sand and silt (fig. 5). The former are initially xerophytic, the latter hydrophytic.

Shores of the cobblestone type may be partly under water during the spring or in wet seasons, but are usually bare in summer and 
during dry years. 'The temperature extremes are great. Furthermore, the occurrence of flood-waters postpones the invasion of pioneers. The freshly exposed stones and gravel possess no vegetation. Algae which may have been clinging to rocks while submerged are killed on exposure to the sun. There is no lichen stage on the rock surfaces. The first plants gain a foothold in

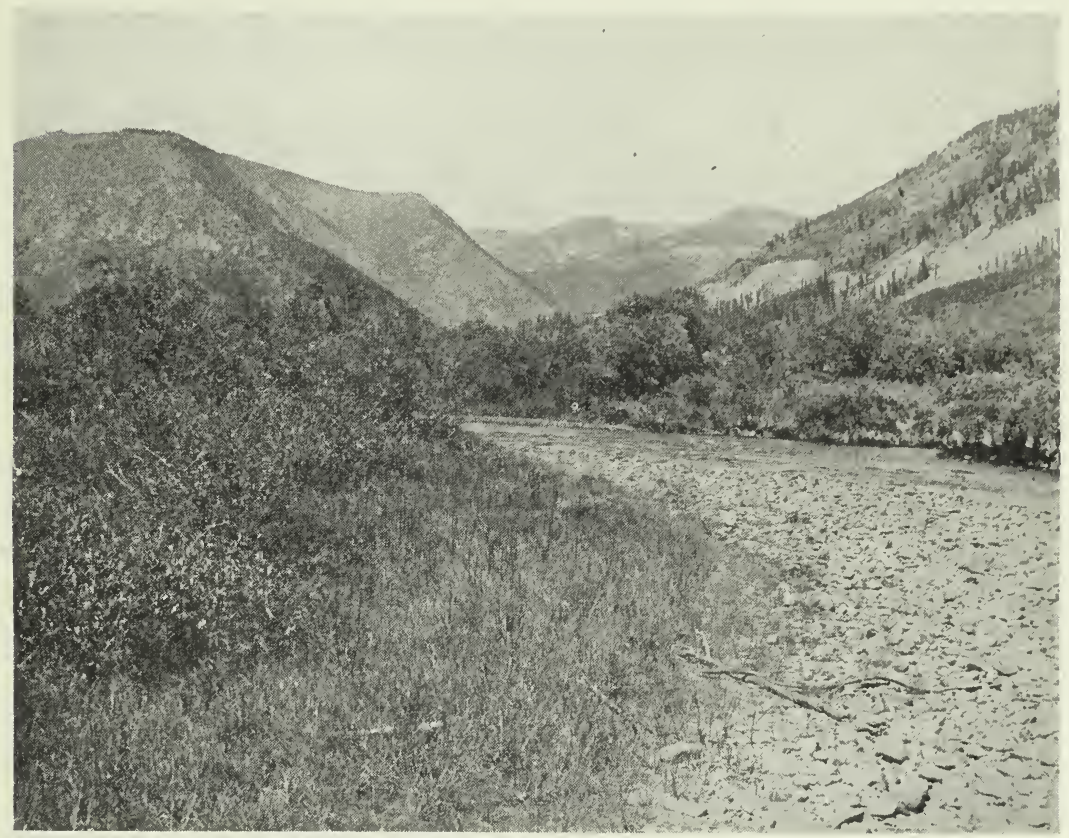

FIG. 4.-Along South Boulder Creek: flood plain of cobblestones invaded by highly mixed plant community; note zone of Carex variabilis bordered outwardly by willow thicket.

the meager accumulation of fine sediment between the stones. Agrostis hiemalis (Walt.) B.S.P. and moss species usually initiate the succession. The individual grass plants form an interlacing, dense mass of fibrous roots which collect and hold sand and silt. These initial plants are followed by a highly mixed community composed of migrants from the sedge moor, willow thicket, meadow, and even dry grassland; in fact, there is no new habitat in the Park, except it is the roadside, where there is such a great number 
of different species. The principal invaders are Deschampsia caespitosa (L.) Beauv., Phleum alpinum L., Poa alpina L., Sporobolus brevifolius (Nutt.) Scribn., Carex variabilis Bailey, Salix chlorophylla Anders., S. padophylla Rydb., Sedum rhodanthum Gray, and Dodecatheon radicatum Greene. The occurrence here of a depauperate form of Erigeron eximius Greene is interesting, as

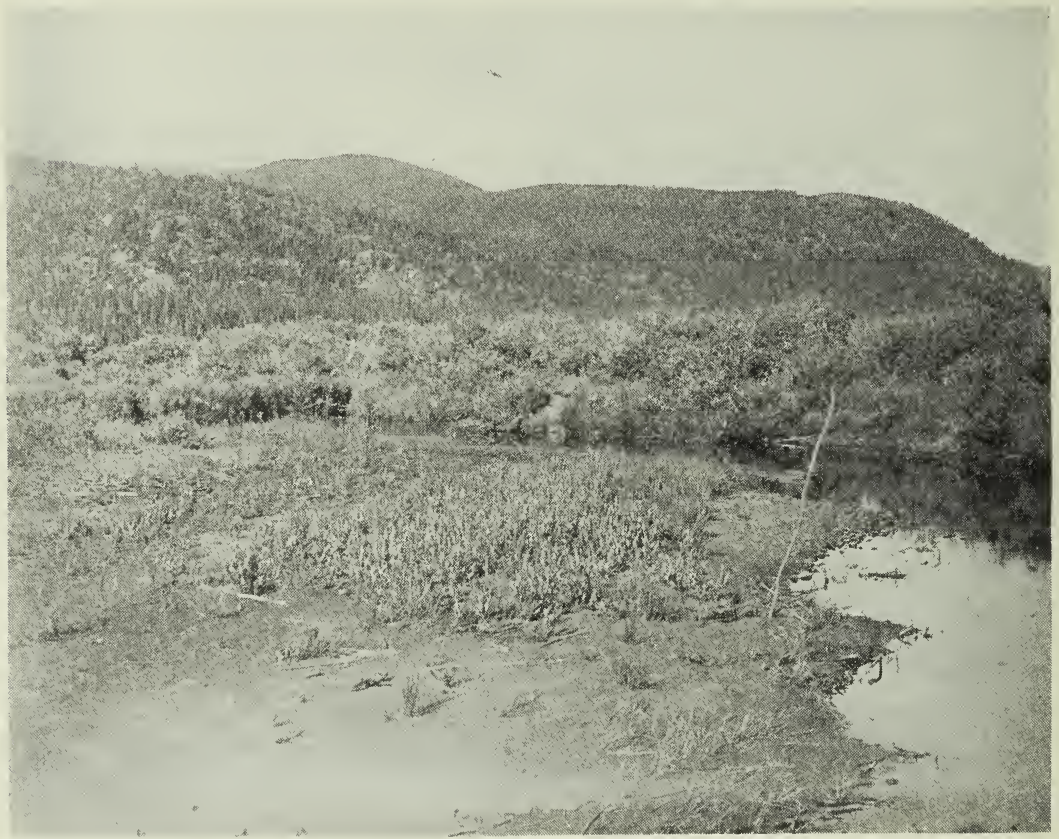

Fig. 5.-Invasion of flood plain of sand and silt: note openness of vegetation, advancing clumps of Agrostis hiemalis and Alopecurus fulvus, and society of young Salix chlorophylla and $S$. padophylla shrubs.

is also the presence of such species as Festuca ingrata (Hack.) Rydb., Rumex acetosella L., Arenaria Fendleri Gray, Sedum stenopetalum Pursh, and Dasiophora fruticosa. In spite of the large number of species, the community is open. As vegetative development proceeds there is a reduction in the number of species and an increase in the number of individuals of the successful species, and increasing mesophytism of the habitat. 
As is quite commonly the rule on flood plains, the first woody plants to gain a footing are Salix species. In this case the invaders are $S$. chlorophylla and $S$. padophylla (figs. 4, 5). After a few years a willow thicket is formed; at the present time extensive willow thickets prevail along the whole course of the stream on ground not far removed from the water level. The willow thicket has a peat deposit from a few inches to over $3 \mathrm{ft}$. deep. As has been indicated, the water level is near the surface at all times, and the association may undergo flooding in the early season.

In the series of successions starting with gravelly and stony stream banks, willow thicket is replaced by a meadow scrub. The presence of tall willows about a terrace lake in the Park has come to be looked upon as evidence of its oxbow origin. The dying out of tall willows in the drier portions of the willow thicket, the quite common presence of relicts of willow thicket throughout the meadow scrub, and the occurrence of small patches of meadow scrub throughout the willow thicket, are all evidences that willow thicket is being succeeded by meadow scrub. Such relicts are usually represented by a few tall Salix padophylla and S. chlorophylla shrubs, and in almost all instances such individuals possess many dead branches.

Meadow scrub attains its typical structure on the middle stream terrace. The characteristic shrubs are Salix glaucops and Dasiophora fruticosa, both of which are low forms as compared with those shrubs dominating the willow thicket. The herbs are those found in the herbaceous meadow of the Park. Meadow scrub commonly has a striking hummocky character. This is due to herbs building up about the shrubs. In places Dasiophora dominates the association. This shrub stands about i8 inches high, and the individuals usually 2 or $3 \mathrm{ft}$. apart. It has a considerable habitat range. In the progressive drying of the meadow scrub, it lags behind as a relict. It is, on the other hand, a common invader of the sedge moor.

The fact that meadow scrub on the middle terrace is laid on gravel indicates that the stream must have moved laterally rapidly on that level, thus giving little opportunity for the development of peat. At the present time the stream is swinging back and forth 
across the valley at a comparatively slow rate, as is witnessed by the formation of peat on the recent levels.

Occasionally sedge moor may precede willow thicket on stream banks, and it is not at all uncommon to find stream banks of shingle remain xerophytic for a long period. The small isolated dry grassland patches throughout the willow thicket association are undoubtedly of this type.

Where the meander approaches its maximum curvature, the force of the stream on the inside of the curve is so slight that fine material is freely deposited. A good illustration of this is to be seen in oxbow 20 (fig. 5). The main current flows through the cut-off channel. A small portion of the stream with only slight carrying power still flows through the oxbow. It has built up a sandy and muddy stream flat. Such a habitat as this has a varied vegetative history. Usually, an association of EleocharisRanunculus is the first to become established. This is the characteristic amphibious community of the Park. The principal species are Eleocharis acicularis (L.) R. and S., E. palustris (L.) R. and S., Ranunculus reptans L., R. natans L., Allocarya scopulorum Greene, and Alopecurus fulvus (L.) R. and S. Eleocharis acicularis builds a dense turf or mat. Allocarya scopulorum may also grow so thickly as to form a rather close growth over the soil surface. Alopecurus fulvus is a constant principal species of the community. Eleocharis acicularis often grows into several inches of water; such plants are sterile. However, by a slight lowering of the water level, the plants spread rapidly both by the underground parts and by seed, and in one season may make good headway toward reclamation of the mud flat exposed. Eleocharis palustris (fig. 6) finds its best expression in some of the oxbow lakes, especially those that have a flat, stony, or gravelly bottom and possess water only a part of the year. In oxbow lakes 8 and 9, for example, almost the entire area over which water stands, for a time at least, is covered with Eleocharis palustris and Ramunculus reptans. Rare associates are Glyceria borealis (Nash) A. Nels. and G. grandis Wats.

The Eleocharis-Ranunculus association is followed usually by sedge moor, in which Carex variabilis is the predominant species, 
and this by a willow thicket of Salix chlorophylla and S. padophylla, or in certain instances the mud flat along streams may be invaded directly by Salix species, and still in other cases, especially where the soil is sandy rather than muddy, Agrostis is initial and is followed by a mixed community similar to that on more gravelly

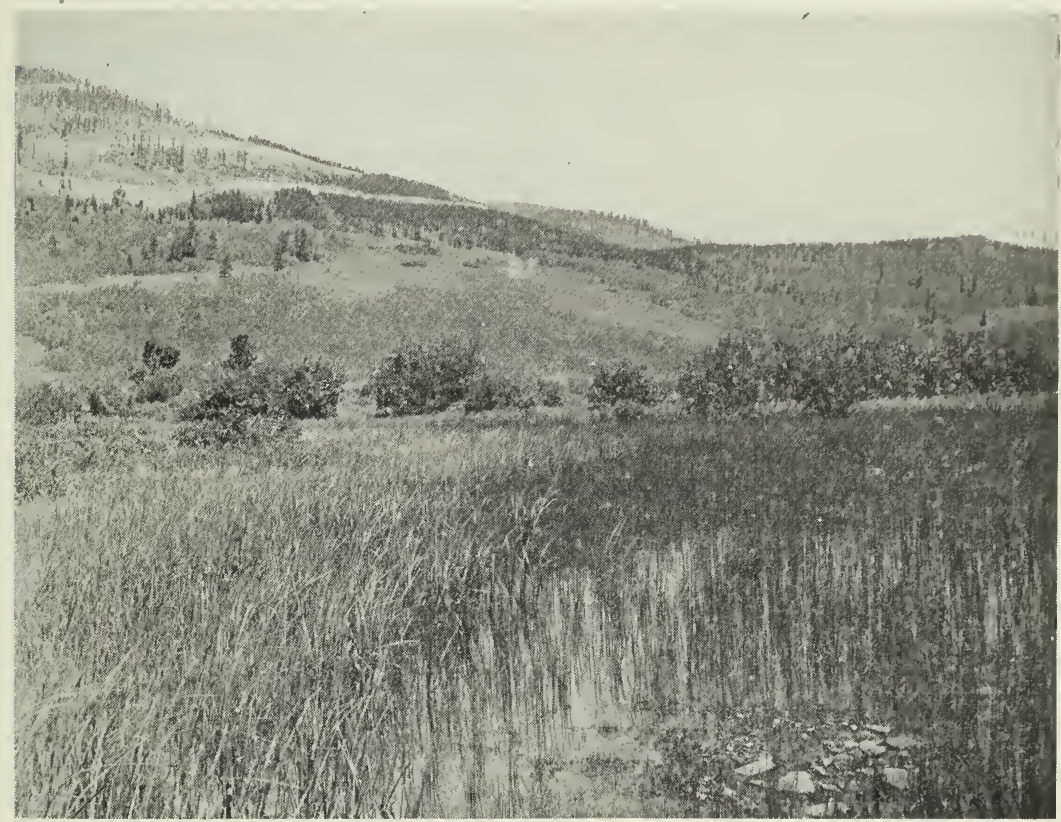

FIG. 6.-Along shore of oxbow lake 9: at shore edge there is an almost pure association of Carex utriculata; bordered on water side by Eleocharis palustrisRanunculus association; tall willows on farther side are relicts of willow thicket stage.

stream banks. This is replaced by willow thicket, which in turn gives way to a mesophytic grassland or meadow scrub.

Oxbow 20 (fig. 7) represents an oxbow in an early stage of formation. Some water is still flowing through the old channel $(\mathrm{egh})$. The cut-off is clearly marked. From $c$ to $d$ a sand bar is being constructed and now almost reaches the water surface and extends from shore to shore. The outlet end of the oxbow will, of course, be the first to close. Then will follow the filling of the inlet, thus completing the formation of a closed body of water having the 
shape of a bow. The shores of the newly formed lake have steep, vertical sides on the outside of the stream curve. On the inside

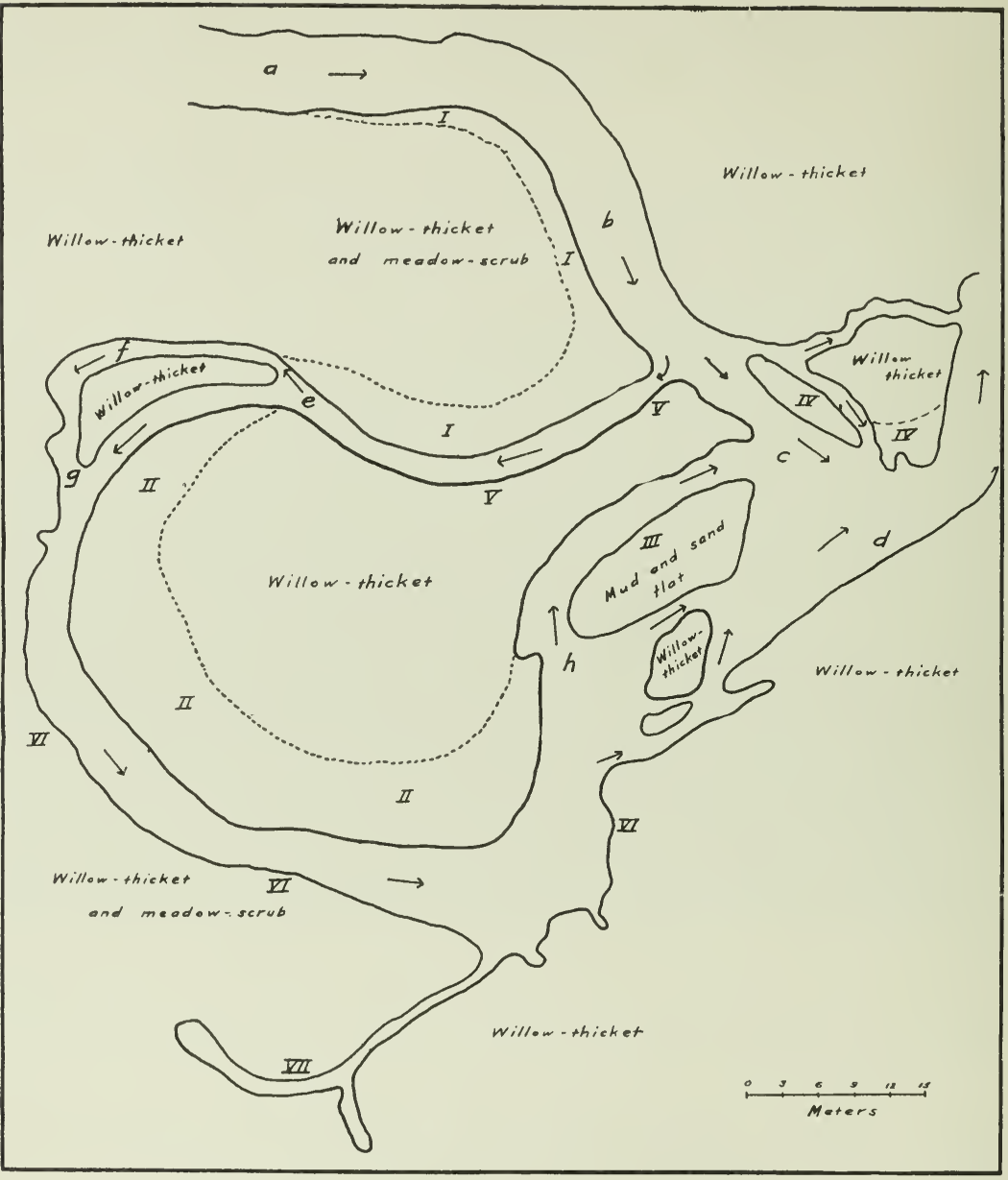

FIG. 7.-Map of oxbow no. 20: an early stage in the development of an oxbow lake; main stream occupies channel $a b c d$; some water still flows through old channel $(\mathrm{ghh})$; from $c$ to $d$ a sand bar is being deposited; shore no. I, composed of sand, gravel, and boulders; at high water the strip may be covered; shore no. II, composed of gravel, sand, and fine silt; the bare soil is being invaded by a mixed association; shore no. III, a mud and sand flat under water a good part of the year; shore no. IV, cobblestone on which no vegetation has secured foothold; shores nos. V and VI, perpendicular erosion shores; "runs" of the kind shown at no. VII are common throughout the Park, being very narrow and with vertical walls. 
of the curves there are gravelly, sandy, or muddy shores of deposition. The future history of this lake is now largely concerned with the activities of plants. In the developing of this oxbow lake Callitriche palustris L. and Batrachium trichophyllum (Chaix.) Bossch. are the first representatives of pond life. The main stream throughout the Park is too swift to allow the growth of any vegetation within it except algae, chiefly Draparnaldia acuta (Agardh) Kuetz. and Prasiola mexicana J. G. Agardh. These are attached to the rocks in the stream bed. They flourish only in swift running water. Batrachium trichophyllum and Callitriche have appeared in the still water back of the sand bar. Encroachment by the vegetation now starts in from all sides, and the area quickly comes to willow thicket. Carex utriculata sometimes becomes interpolated at the margin between willow thicket and open water. It is an important invader of these shallow oxbows. It is frequently succeeded by Carex variabilis, which is in turn followed by willow thicket. An oxbow that has had its connection with the main current severed usually passes through the same stages of succession found about lake shores.

Oxbow 3 is a somewhat different type from the preceding. The lake is shallow and has a muddy bottom, over which numerous small rocks are scattered. The orignal rock and gravel stream bed is thus still visible. The lake is free from water during the latter part of the season. Alopecurus fulvus is dominant on the muddy bottom. Associates are Ranunculus reptans, Eleocharis acicularis, and Sparganium angustifolium Michx. Carex utriculata is rapidly invading the Alopecurus society. Mixed with Carex is Glyceria americana, Alopecurus fulvus, and a great deal of moss. Moss often invades the Carex utriculata association, preparing a substratum upon which willow thicket may build more readily.

Oxbow 5 is a small and shallow pond which undergoes periodic drying. There is a well developed Eleocharis-Ranunculus association on the sandy bottom. It is being invaded by Carex utriculata, after which comes willow thicket.

Oxbow 6 exhibits a pond that is now almost filled with vegetation. A very small area of open water still remains. The lake was narrow and filled in a manner normal to gravelly or muddy shores, 
that is, by the invasion of willow thicket. There is no vestige, however, of the first associations of these shores. Carex utriculata occupies the wettest part of the area. It is followed on all sides by the springy sedge moor of Hypmum, Carex variabilis, and $C$. canescens L. Here Carex variabilis is building upon the moss. The principal shrub succeeding C. variabilis is Salix chlorophylla.

Oxbow lakes 8 and 9 differ in a marked degree from all others in the Park. It will be seen that they are the only lakes of oxbow origin that occur on the middle terrace. Obviously they are physiographically much older than those of the lower stream terrace. They are very shallow and annually dry up. In spite of their age, they have not filled to any extent. Rock and coarse gravel, with but comparatively little finer material between, make up the pond bottom. This lack of plant débris is associated with periodic drying, and the exposure of the area to the winds. Late in a particularly dry season, the level bottom becomes dry and the strong winds blow away the material that accumulates. The chief associations over almost the entire lake bottom is an open one of Eleocharis palustris and Ranunculus reptans (fig. 6). Glyceria borealis and $G$. grandis are rare associates. About the shore edge Carex utriculata is slowly working inward. Carex variabilis or meadow scrub may come to the water's edge. A few clumps of Salix chlorophylla and $S$. padophylla at the edge are relicts of the old stream bank stage. Such individuals have numerous dead and dying branches.

East Lake (figs. 8, 9) is an old oxbow of South Boulder Creek, from which it is now separated by about $250 \mathrm{ft}$. The intervening area is a sedge moor alternating with willow thicket. Through this the lake outlet feebly flows. The old shore line of the creek is distinct. Mertensia ciliata (Torr.) Don. and Senecio triangularis Hook., typical streamside plants in the region, may be found sparingly in the willow thicket of the lake. Salix chlorophylla and $S$. padophylla, with the two associated herbaceous species, are relicts of a streamside flora. There is further evidence of the oxbow origin of East Lake. The stream cut into the terminal moraine and made a strong curve toward the southwest, working into its bank almost at right angles. As is happening at many places in the present 
stream course, the shores were eroded and an inlet of considerable width and depth formed. We take it that the position of this is represented by the long tongue of sedge moor that extends from the lake edge to the meadow. Soil borings here show deep deposits of peat extending to the meadow.

At present, East Lake has a flat bottom and a uniform depth of about I ft. The bottom is of mud. The lake's development is

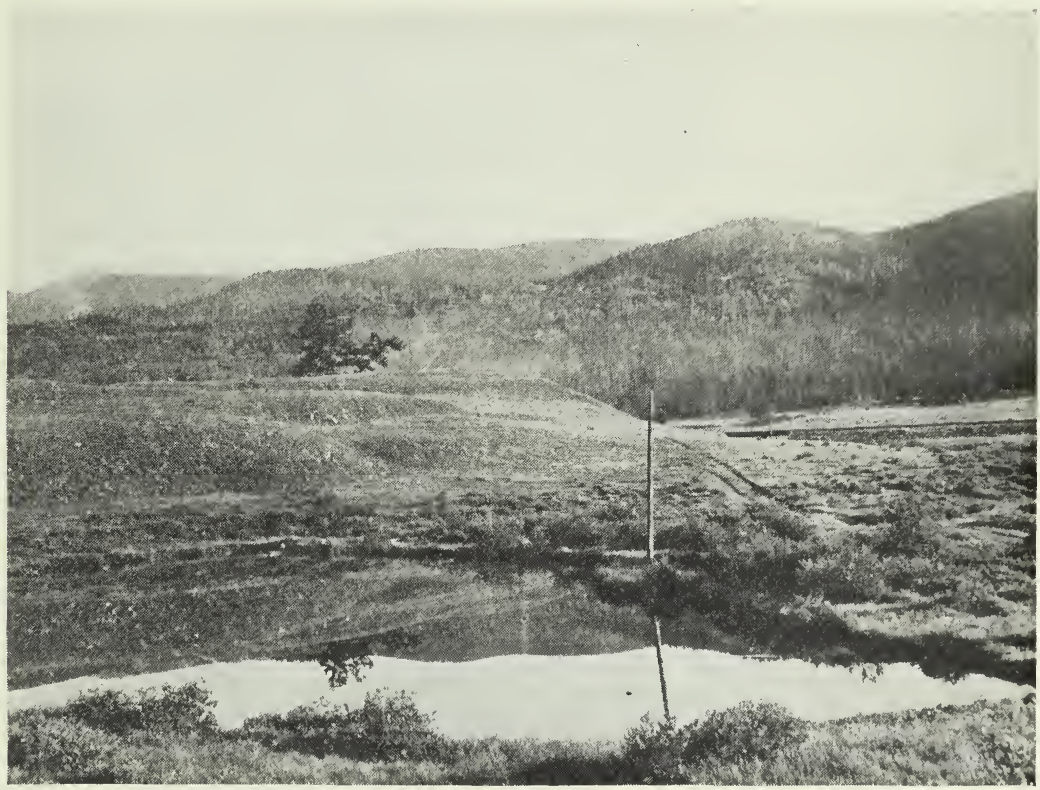

FIG. 8.-View of East Lake, of oxbow origin; beyond is portion of large terminal moraine.

natural and typical of an oxbow belonging to the lower terrace. The associations in and about the pond are arranged concentrically, particularly along the west and south sides. A small amount of Batrachium and Callitriche is found in the water. Carex utriculata makes a pure association chiefly along the west shore, where it is rapidly pushing out into the water. The plant is $\mathrm{I}-2 \mathrm{ft}$. high and spreads by means of creeping rootstocks. Its typical habitat is still water not exceeding I ft. in depth. The amount of plant remains annually deposited by it is considerable. Furthermore, it 
breaks wave action and thereby facilitates the accumulation of sediment between its closely crowded erect stalks. It is followed by the typical sedge moor, and this by willow thicket or meadow.

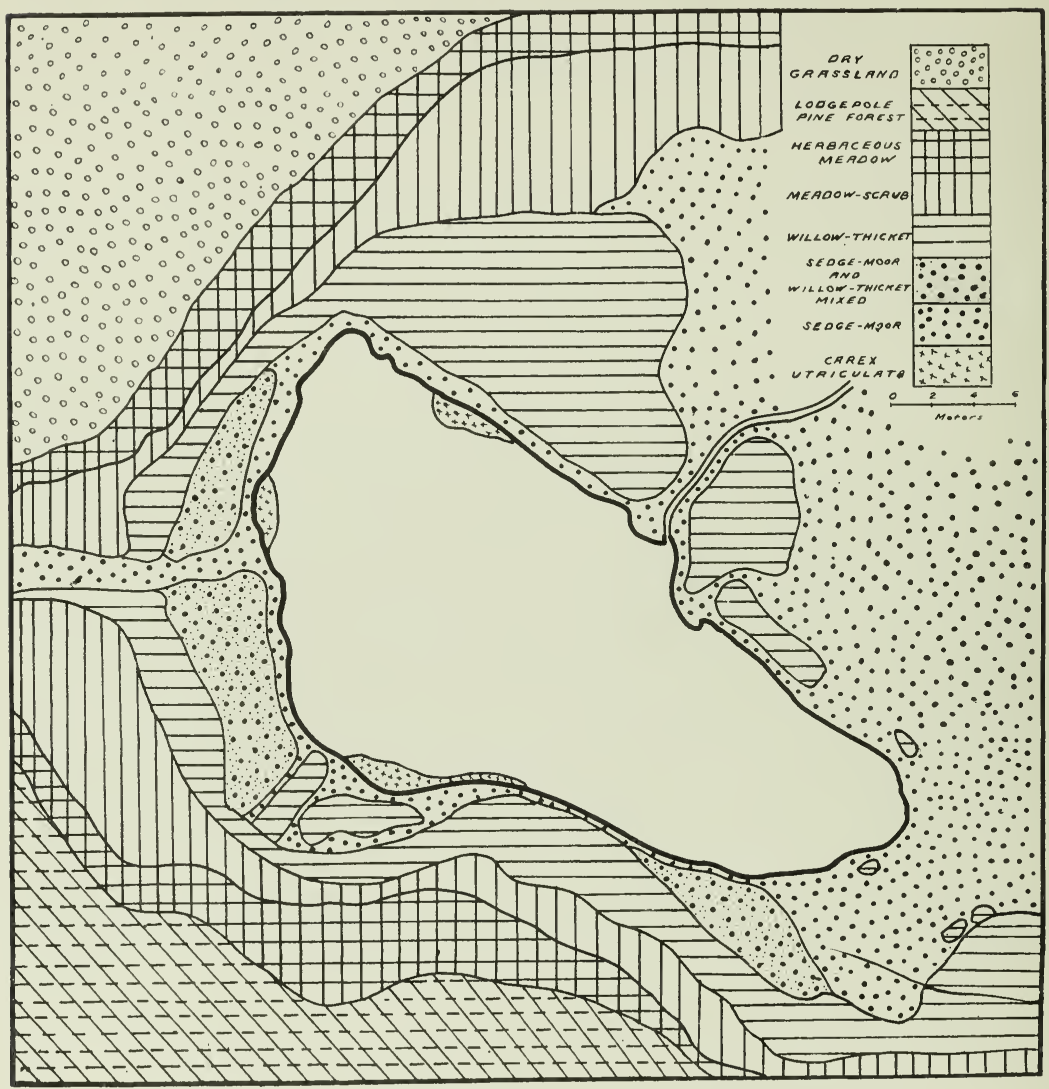

FIG. 9.-Map of East Lake, showing surrounding plant associations

Carex utriculata, however, is not the only agent in the invasion of the open water. Fig. Io shows a section of the shore edge and sedge moor. It will be noted that there is a distinct elevated rim at the water's edge. 'This elevated rim is present almost entirely about the lake. Such a rim is commonly found along the streams, and is the result of stream cutting. Its occurrence about a lake may be taken as an evidence of its oxbow origin; not conclusively, 
however, for the rim is also a feature of glacial lakes such as Redrock (20) and Park, which are not genetically related to stream topography. In these it is no doubt formed by the sapping action of ice. Of course, stream action and ice action may be cooperative factors. At any rate, whatever its origin, once established the rim is maintained by vegetative building. At East Lake the rim about the edge has a mean height of about i 6 inches. In texture it is a loose and spongy mass and consists of living and decayed

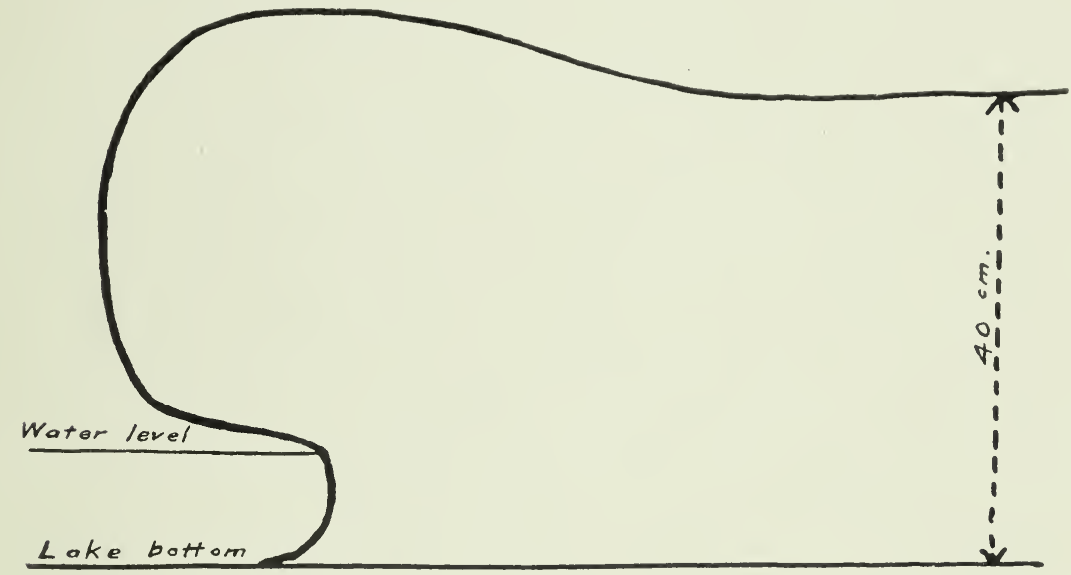

Fig. I0.-Section of "rim" and sedge moor at East Lake: rim which overhangs water has loose and spongy texture and consists of living and decayed plant material, largely masses.

plant material, largely mosses. Just back of the rim the soil is wetter, more compact, and the character of the vegetation somewhat different. Being actually drier than the moor a foot or so landward, it supports an assemblage of plants, many of which would scarcely be expected to grow at the water's edge. Salix chlorophylla and Dasiophora fruticosa are the important shrubs of the rim. The seeds lodge and germinate on the bare, more or less perpendicular, wall of the rim, and the young plants curve outward and upward over the water. Other characteristic rim plants are Betula glandulosa, Sedum rhodanthum, Dodecatheon radicatum, and Poa leptocoma Bong. The importance of moss in the building of the rim should be noted. As the rim slowly builds out over the 
water, it sinks by its own weight, thus forming the flatter, lower, and more compact part just back from the edge. Willow thicket is invading the moor in many places. It is replaced by meadow scrub. At several points sedge moor passes directly into sedge moor, thus omitting the thicket and scrub stages of succession.

The principal species in the sedge moor of Boulder Park is Carex variabilis. It is a peat forming species. In reaction, the soil of the sedge moor is very slightly acid. The plants of the association stand close together. There is always an abundance of moss, which is of great importance in the building of peat. The sedge moor becomes marshy during the spring and early summer and after heavy rains. Then, the water aids in the packing down of dead sedge plants. The water table is always high and the soil water content high throughout the year. Stratification occurs to some extent. The following species form a ground layer: Androsace subumbellata (A. Nels.) Small, Galium trifidum L., Crunocallis chamissonis (Esch.) Greene, Veronica serpyllifolia L., Alsine longifolia (Muhl.) Brit., moss, and liverworts. Caltha rotundifolia (Huth.) Greene is an important component of the sedge moor. It is not a shade plant and hence does not do as well in the denser parts of the association as in more open spots.

Petasites sagittata Gray is prevernal in the sedge moor. Caltha is the characteristic species of the spring aspect (May I5-July I). The summer aspect (July I-August I 5 ) is marked by a large number of sedges, grasses, and other herbs, most important of which are Carex variabilis, Deschampsia caespitosa (L.) Beauv., Hierochloa odorata (L.) R. and S., Sedum rhodanthum Gray, Pedicularis groenlandica Retz., and Agrostis hiemalis (Walt.) B.S.P. The appearance of gentians the latter part of August ushers in the autumn aspect (August I5-October I). Chief of these are Pleurogyne fontana A. Nels. and Gentiana plebeya Cham. During the winter the sedge moor is a level expanse of withered shoots and leaves, chiefly Carex.

As compared with drier associations, the seasonal aspects of the sedge moor change slowly. The reason for this is partly the fact that Carex hides other forms growing within it, and furthermore to the actual paucity of species in this area as compared with drier 
situations. More important, however, are soil, temperature, and moisture conditions. The maximum seasonal variations of soil temperature in typical associations during the summer of I909 (I3), as seen in the following table, will give some explanation of the rapidity of change in the seasonal aspects.

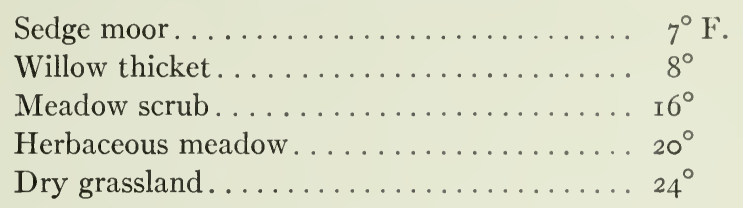

It will be noted from this that the sedge moor has the least variable soil temperature throughout the growing season. This condition is due for the most part to the amount and texture of the vegetative cover, and also is intimately related to the soil water content. Sedge moor vegetation screens the soil efficiently. Moreover, as a result of its high water content the specific heat of sedge moor soil is high and its conductivity of heat low. In the dry grassland, on the other hand, there is an absence of a dense vegetative covering. Here the soil has a low specific heat, due to its dryness, and its heat conductivity is great. D Dry grassland heats up more rapidly and cools off more readily and to a greater depth sooner than either meadow or sedge moor. As regards soil temperature and soil moisture, the sedge moor shows less seasonal variation than either meadow or dry grassland. This condition appears to be correlated with the lack of marked seasonal aspects. Edaphic conditions within a community control the seasonal changes of the vegetative covering.

We have described the stages in the development of the flood plains of a mountain park. The oxbows and oxbow ponds are prominent features of these flood plains. Boulder and gravel shores or sand and fine silt shores are the initial habitats. They culminate in a temporary meadow climax. Two exceptionally distinct ages of flood plains are represented: a recently formed one now in the willow thicket stage, and an older one on the middle terrace in the meadow or temporary climax stage. A consideration of the fate of the meadow will be discussed later, after treatment of the glacial lake and dry grassland series of succession. 


\section{GLACIAL LAKE SUCCESSION}

The origin of Park and Filled Lakes, the only glacial basins in Boulder Park, has been discussed. It was pointed out that these two bodies occupy the positions of two ice cores that were left on the valley floor on the retreat of the first ice mass. Immediately following the melting of these ice cores there was left a cold water lake with bare gravel and stony shores. Park Lake was formerly of much greater size; the limits of the old shore may be clearly seen on the west side of the present body of water. This filled area is now in the sedge moor stage of development, as is also Filled Lake. We may gain some idea of the early stages in the development of the shore vegetation by studying the alpine lakes which are found in abundance 6 or 8 miles west of Boulder Park. However, this difference exists: alpine lakes are comparatively well protected by cirque walls from wind effects, whereas those of Boulder Park are in the open. It is believed that this difference explains the tardy development of forest growth in the Park, and the maintenance of the temporary climax grassland.

In the lakes and ponds of Park Lake, algae are the only free floating plant life. Besides the numerous microscopic algae which constitute a portion of the plankton of these waters, Mougeotia laetevirens (A. Braun) Wittr. and Spirogyra Weberi Keutz. make up large floating masses along shores undisturbed by waves. Anabaena flos-aquae (Lyngbye) Breb. becomes conspicuous in late July when it appears as "water bloom" over the entire surface of the lake.

Sparganium angustifolium Michx. (fig. I I) forms a well defined aquatic community along the shore edge out to a depth of about $2 \mathrm{ft}$. It is of much importance in the aquatic successions. It grows equally well on a mud or gravelly bottom. A dwarf form occurs at the south of Park Lake on a low, flat area over which the water level fluctuates. Here the plants grow but a few inches high, and possess short, rather thick, leaves. Such plants mature fruit normally. Callitriche palustris L. is found in shallow water. It is most abundant where protected from wave action. Batrachium trichophyllum (Chaix) Bossch. is one of the first aquatics to secure a foothold in the ponds of the Park. It is the most 
important aquatic in the filling process. Potamogeton foliosus Raf., P. lonchites Ruck., P. alpinus Balb., P. interior Rydb., P. lucens I., and Myriophyllum spicatum L. are other rather rare aquatics to be found here.

Aquatic plants play an important part in the life history of the lake. On the flat, mud shores the Sparganium association is

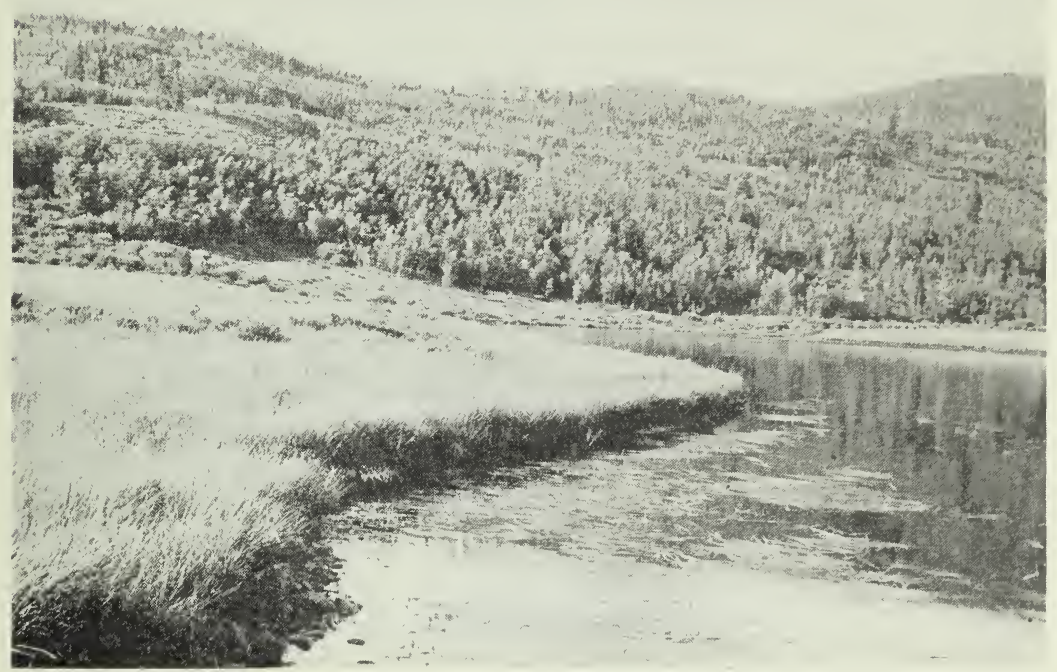

FIg. II.-West shore at Park Lake; note Sparganium in shallow water, and zones of sedge moor and willow thicket.

immediately succeeded by the Elcocharis-Ranunculus community. This is well shown at the southwest shore (fig. I 2). This shore is flat and gravelly or muddy, with a few small boulders scattered about. It is perennially covered with an inch or so of water up to about July I, after which time it is a mud and gravel flat. Dwarf forms of Sparganium angustifolium flourish in this habitat. Eleocharis acicularis here, as elsewhere in such habitats, is the chief invader of the bare soil. Following close behind and upon pure tufts of Eleocharis come Allocarya scopulorum and Alopecurus fulvus, in the 
order named. Alopecurus grows in caespitose clumps $3^{-6}$ inches in diameter. These tufts are the nucleus for the growth of such plants as Epilobium Hornmannii Reich., Agrostis hiemalis, and Veronica serpyllifolia L. Following the establishment of these herbs come Carex variabilis, C. lanuginosa Michx., C. festiva Dewey, Deschampsia caespitosa, Phleum alpinum, and Poa leptocoma. As

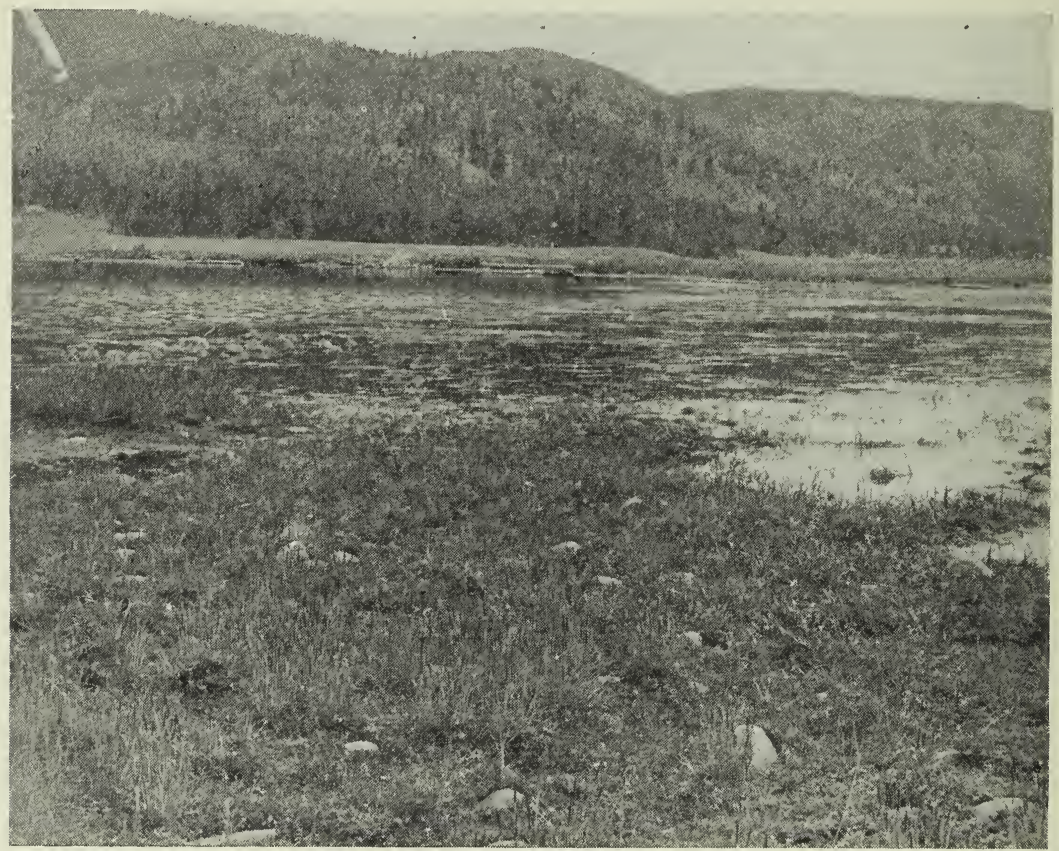

FIG. I 2.-View of Eleocharis-Ranunculus association at southwest corner of Park Lake; community occupies a broad mud flat; note tufts of Alopecurus fulvus.

at East Lake, sedge moor may be succeeded directly by herbaceous meadow, the Carex festiva society being the first meadow community to become established.

Filled Lake is one of the most interesting features of the Park. This old lake bed is now in the sedge moor stage of development. The shore line is still quite distinct, made more so by the vegetative growth than by any topographic condition. Early successions now in operation at various places in the Park are undoubtedly similar to those which led up to the present sedge moor stage in Filled Lake. 
The association immediately preceding the present one and the future changes are quite clear. The sedge moor is now dominated by Carex variabilis and C. utriculata, alternating and freely mixing. Obviously, C. variabilis has followed upon C. utriculata. Mosses

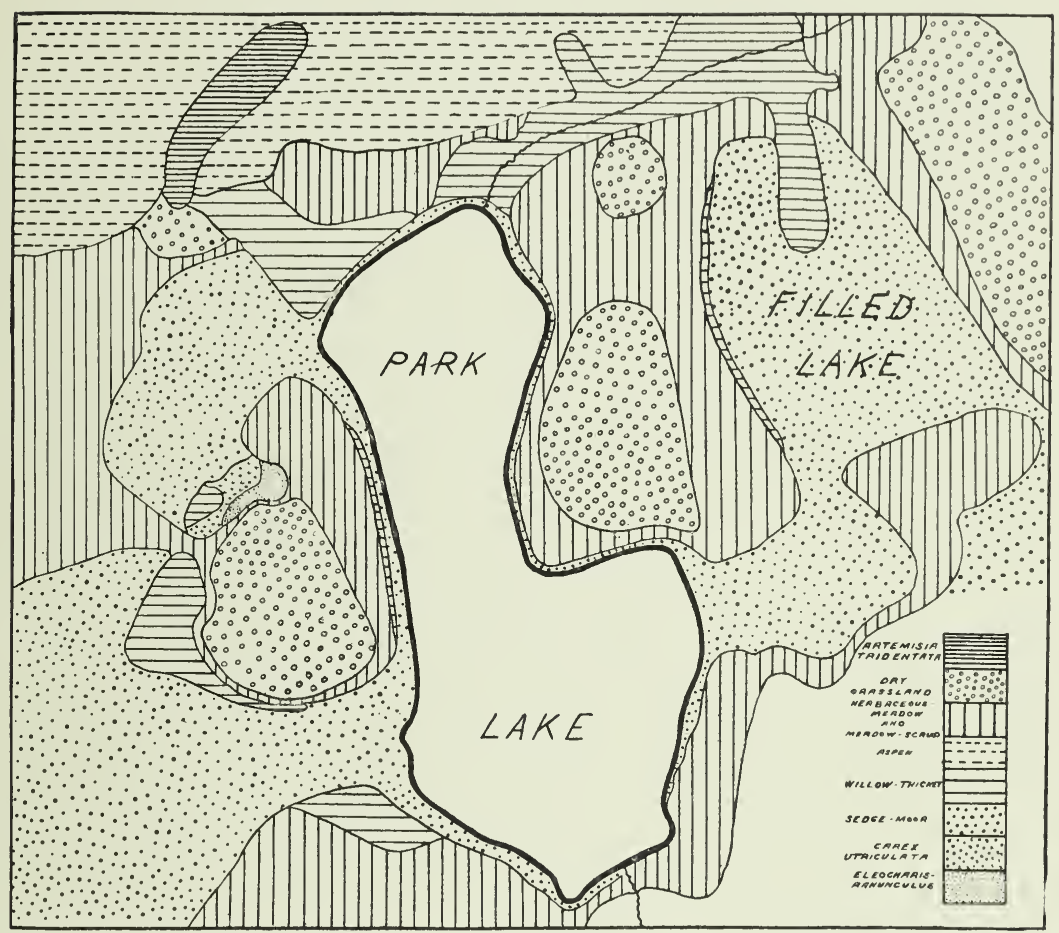

FIG. I3.-Map of Park and Filled Lakes

are an exceedingly important element in the building up of sedge moor.

If one stands at the old shore line and looks out over the flat, sedge-covered lake floor it is seen to be divided into two quite distinct parts: (I) the half nearer the outlet is lighter in color, due to the predominance of sedges, of which $C$. utriculata forms a good proportion; (2) the north half is darker, due to a pronounced admixture of Deschampsia, and a greater proportion of $C$. variabilis as - compared with C. utriculata. The north half of the lake is drier. 
This would be expected, since it is further removed from the outlet and is adjacent to the hill at the north, from which it has received considerable wash material.

Scattered throughout the sedge moor, and particularly in the upper half mentioned, are numerous clumps of vegetation. These are slightly elevated above the general level and vary from I to $3 \mathrm{ft}$. in diameter. The nucleus of a clump is usually a Salix chlorophylla shrub. This species is an early invader of sedge moor throughout the Park. Building in and around it are such early invaders as Sedum rhodanthum, Alsine longifolia (Muhl.) Brit., Arabis hirsuta Scop., Cerastium occidentale Greene, Geum strictum Ait., and Dasiophora fruticosa. The clumps may also originate about a

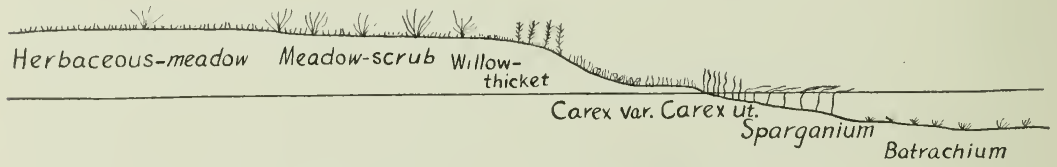

FIG. I4.-Ideal section at west shore of Park Lake

Dasiophora shrub or Deschampsia tuft. All the shrubs are young. Ring counts of Dasiophora show the large majority to be I $^{-1} 5$ years of age. Salix shrubs are older on the average. The sedge moor is rapidly being converted into meadow.

At the northwest shore of Filled Lake there is a shallow shelf extending outward from the shore line. The limits of this shelf were determined by making soil borings. These were simply used as a check on the determination of its limits by the vegetative covering. In fact, the presence of the shelf here was called to the attention by a rather marked difference in the vegetation as contrasted with that beyond. It is mentioned simply to illustrate transition conditions between sedge moor and meadow. Here Deschampsia caespitosa is predominant. Young Dasiophora shrubs are very uniformly distributed throughout. Sedges, relatively, are not an important component. Secondary species are: Hierochloa odorata (L.) R. and S., Phleum alpinum L., Poa leptocoma, Cerastium occidentale, Alsine longifolia, Caltha rotundifolia (Huth.) Greene., Sedum rhodanthum, Geum strictum, Potentilla gracilis, Valeriana 
ceratophylla (Hook.) Piper, Achillea lanulosa Nutt., Antennaria parvifolia Nutt., and Crepis perplexans Rydb. The large number of characteristic meadow species will be noted.

The depth of the peat deposit in the lake was determined throughout. In the center it is over ro $\mathrm{ft}$. deep. From here the depth gradually decreases toward the shores. The rate of increase in depth may be judged by a set of borings made every $5 \mathrm{~m}$. along an east-west line to the center of the area. Starting at the east shore this series shows depth (in $\mathrm{cm}$.) as follows: 40-46-47-43-70I36-I80-2 I 2-220-258-over 300.

Borings show that the lake has been filled almost entirely with the stems and leaves of Carex. The surface soil is loosely packed plant material, readily separated into layers, indicating seasonal deposition. The upper 6-8 inches are light brown in color; below this, the layers become darker and more compact. This soil exhibits a slight acid reaction.

It will be recalled that, at East Lake, Salix chlorophylla is a characteristic plant of the raised rim at the water's edge. A similar condition exists here. At the west shore there is a very distinct line of this shrub, on a more or less evident rim; at one time these formed a fringe at the water's edge. Back of this rim is a belt averaging about $20 \mathrm{ft}$. wide, clearly the old sedge moor of the lake shore. Beyond this is a meadow scrub, followed by herbaceous meadow, then dry grassland. The dry grassland is not the outcome of progressive drying of the meadow, as the zonation might suggest, but it represents a stage in a xerarch succession on the glacial gravel of the high terrace.

\section{DRY GRASSLAND SUCCESSION}

The rapid drainage of the lake which covered the entire park left a level, uniformly gravelly, area exposed to the drying and mechanical effects of the winds, and the extremes of diurnal and yearly temperatures. Lichens and Selaginella densa are the chief pioneers of the glacial gravels here. The latter is a mat former, and on the mats other plants gain a foothold. Its reaction upon the habitat, in holding the soil, adding humus, and retaining water, favors the entrance of such xerophytes as Erigeron multifidus Rydb., 
Sedum stenopetalum, Potentilla concinna Rich., Carex stenophylla Wahl., Aragallus Lambertii (Pursh) Greene, Chrysopsis villosa (Pursh) Nutt., Comandra pallida A.DC., Arenaria Fendleri Gray, Artemisia frigida Willd., and A canadensis Michx.; simultaneously, there is an incoming of such grasses as Muhlenbergia gracilis Trin., Danthonia Parryi Scribn., Festuca saximontana Rydb., Poa interior Rydb., and Koeleria cristata Pers. There results a xerophytic grassland which has been designated "dry grassland." It is a persistent and long-lived plant community.

The dry grassland of Boulder Park has been the object of extended study by Ramaley (14, I5, I6, I7). The association is preeminently one of coarse, gravelly, thin soils. Humus is conspicuously scarce. The soil temperatures run high throughout the vegetative season, and the soil water content low, at times falling below the wilting coefficient. The area is well exposed to the winds, and snow does not accumulate to any extent. Ramaley has shown that 70 per cent of the most important dry grassland plants are shallow rooted, and that 33 per cent of them are rhizomatous; moreover, many of those which do not bear rhizomes have much branched caudices. Practically 9r per cent of the dry grassland plants are perennial. These facts point to the extreme xerophytism of the habitat.

The dry grassland is an open community; bare ground composes about ${ }_{5}$ per cent of the whole area during the month of July. There is ample opportunity for seeds to find open territory; but the life of the seedling is a precarious one. There is a lack of soil water, droughts are frequent in summer, the transpiration rate is high, and there is a lack of winter snow cover. These conditions exclude the invasion of trees and many mesophytic plants.

Dry grassland has all appearances of being the ultimate vegetation throughout the Park, under present climatic and physiographic conditions at least. However, slowly but surely it is being invaded in places by meadow; a series of dry years may see the drying up of meadow, the fragmentation of plant parts, and their removal by wind, thus reinstating the dry grassland stage. The resultant is a slow encroachment of dry grassland by mesophytic grasses and other herbs. As has been indicated, if physiographic and climatic 
conditions remain unchanged, the process of encroachment will be extremely slow. However, physiographic agencies are destroying the dry grassland habitat at a rate which exceeds that of biotic agencies. At many points the high terrace is being eroded by the stream, and invariably the flood plain temporarily culminates in meadow; again, débris is accumulating at the bases of slopes and in the depressions between glacial hummocks. On this fine grained and deeper soil, with its greater water retentiveness, meadow species become well established; hence it is seen that the combined activities of biotic and physiographic factors are resulting in the slow disappearance of the dry grassland and the establishment thereupon of a mesophytic grassland. Fuller (6) points out that whereas the hydrarch succession of Boulder Park is closely comparable to that of the Illinois prairie, the Park area exhibits a xerarch succession comparable to nothing found in Illinois.

Two types of meadow are displayed in the Park which we have designated "herbaceous meadow" and "meadow scrub." The latter consistently occupies moister situations, and very frequently precedes herbaceous meadow in the succession.

The seasonal aspects and detailed structure of the meadow need not be entered into extensively here. REED (2I) has given us a report of the chief meadow societies in the Park, together with a list of the meadow plants with their frequency and soil moisture index.

Carex festiva forms distinct meadow societies on the middle terrace and about the lakes. Where the slope of the lake shore is gradual, sedge moor immediately joins on to this society. Its chief associates are Deschampsia caespitosa, Phleum alpinum, Potentilla gracilis Dougl., Poa Buckleyana Nash, and Poa pratensis L. A conspicuous society of Pedicularis Parryi Gray occurs just outside the Carex festiva society in soil that is drier and more shallow. A quadrat census of the plants of the society showed the principal species to be Potentilla gracilis, Astragalus alpinus L., - $\quad$ Pseudocymopterus sylvaticus A. Nels., and Chondrophylla Fremontii (Torr.) A. Nels. The most unobservant person would remark about the well defined limits of the Pentstemon procerus Dougl. society. It extends in a semicircle about the south flank of a low, 
morainal elevation on the east side of Park Lake, and is also characteristic of glacial sinks. Grasses do not form a close growth, but other herbaceous species predominate. Troximon glaucum Nutt., Potentilla gracilis, and Valeriana edulis Nutt. are the principal associates. A society, the main representatives of which are

DIAGRAII OF PLANT SUCCESSION, BOULDER PARK, COLORADO

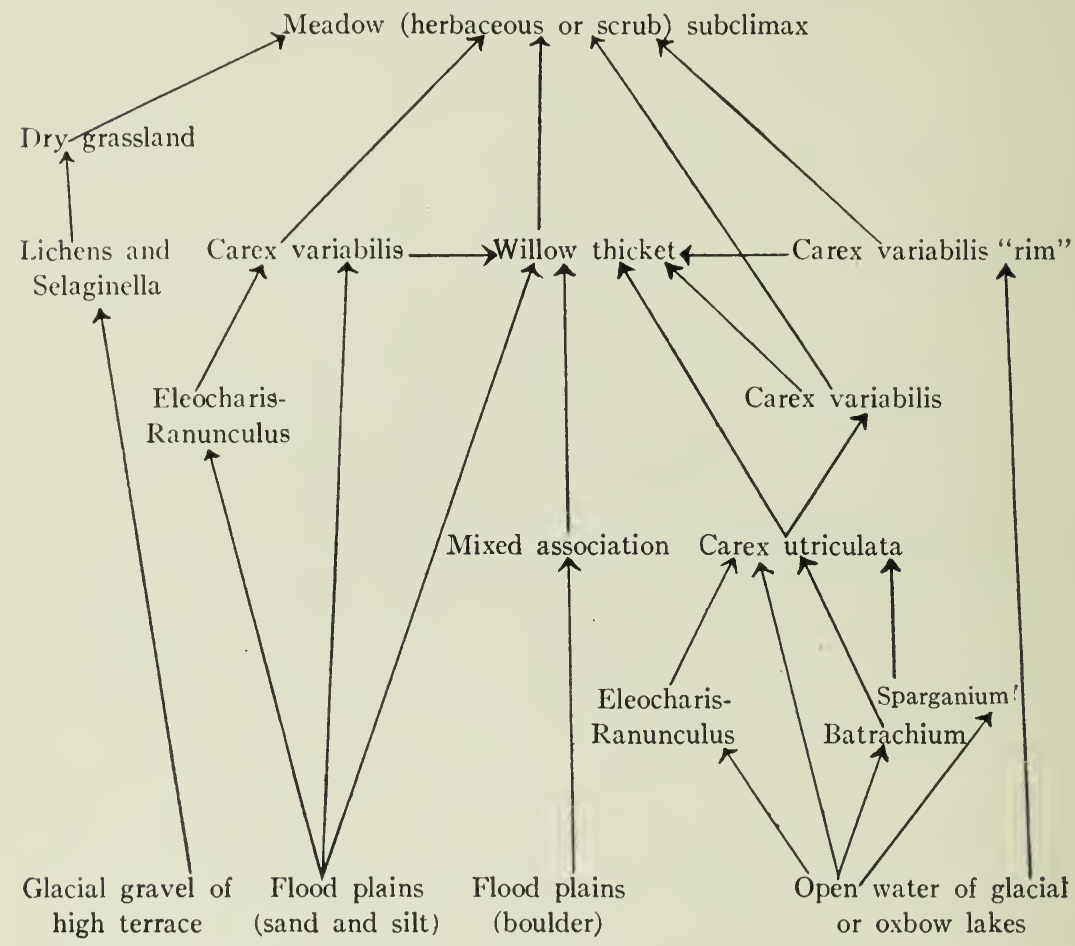

Erigeron macranthus Nutt., Campanula Parryi Gray, and Eriogonum subalpinum Greene, is characteristic of the meadow that immediately adjoins dry grassland. Associated species are Galium boreale L., Achillaea lanulosa Nutt., Stipa Nelsonii Scribn., Poa interior Rydb., and Koeleria cristata (L.) Pers.

\section{Discussion}

Based upon the water content of the initial habitat, the successions may be classified as hydrarch and xerarch. The hydrarch 
succession involves the glacial lakes, and the flood plains with deposition banks of silt and sand; the xerarch succession involves the gravels laid bare by the rapid drainage of a glacial lake which at one time occupied the greater part of the Park, and the flood plains with shores of coarse gravel or shingle. The stages in these series lead to a temporary meadow climax (subclimax). The climax is reached much sooner by the hydrarch than by the xerarch series. In fact, much of the high terrace is now in the dry grassland stage, which under existing environmental conditions, incident to the topographical setting of the Park, promises to be long standing. However, there is ample evidence that even under these circumstances it is being slowly replaced by meadow. Moreover, the physiographic operations now in progress, namely, the erosion of Boulder, Meadow, and Trestle Creeks, and the accumulation of wash material at the bases of slopes, look toward the disappearance of the dry grassland habitat and the ushering in of meadowland.

The question now arises, are trees advancing upon the meadow? The forest associations bordering the Park are as follows: (I) aspen (Populus tremuloides Michx.), (2) lodgepole pine, (3) (Pinus Murrayana Oreg. Com.), and (3) Engelmann spruce-subalpine fir (Picea Engelmannii [Parry] Engelm.-Abies lasiocarpa [Hook.] Nutt.). Aspen often forms a fringe between the coniferous associations and the meadow of the open Park. This relation prevails throughout the Rocky Mountain region. Wherever the developmental series has led up to the meadow stage, however, as it has in Boulder Park, this stage bids fair to hold its ground against the invasion of trees, thus constituting a climax (subclimax) of long duration. The principal factor involved here is competition. It may occur to one that, although the competition of meadow species prevents the forestation of the open Park, there is nothing to prevent the dry grassland with its abundance of open ground being invaded by trees. In this connection it may be said that the exposure of the dry grassland to excessive evaporation as conditioned by wind, temperature, and the lack of a snow cover makes a situation in which trees find it impossible to get a start. The climatic climax of the region is a forest of Englemann spruce-subalpine fir. 
In comparing the mountain lakes with those of the plains and lower altitudes generally, it is striking that those of lower elevations support the richer aquatic vegetation. The ponds of Boulder Park do not have many species commonly known as belonging to the water habitat. For example, there will be noted the total absence of species of Lemna, Hydrocharis, Ceratophyllum, Utricularia, Riccia, Azolla, and Salvinia, free floating species common at lower altitudes. Of these, several Lemna spp. and Utricularia vulgaris have been collected at elevations in Colorado as high as Boulder Park. Many submersed and emersed fixed species are not to be found here. Among such may be mentioned species of Nitella, Isoetes, Naias, Elodea, Nymphaea, and a number of Potamogeton spp. Several other species of Potamogeton, Nymphaea polysepala (Engelm.) Greene, Isoetes Bolanderi Engelm., I. paupercula (Engelm.) A. A. Eaton, and Naias gaudalupensis (Spreng.) Morong are reported from a few lower altitudes in Colorado.

The scarcity of aquatic plant life in the lakes and ponds of the Park is in part due to the coldness of the waters during a considerable portion of the year. Moreover, the marsh type of vegetation here is meager, and little shelter is offered to many free floating forms. The lakes and ponds in Boulder Park contain very soft water. No doubt the same is true of most high altitude lakes. Nearly all plains lakes, however, are rich in alkali salts; bicarbonates of calcium and magnesium, also of potassium and sodium, are quite universally present. A number of workers $(\mathbf{2}, \mathbf{5}, \mathbf{2 5})$ have noted that waters rich in lime carbonates have a richer aquatic flora and fauna than soft waters. In the absence of free carbon dioxide, water plants may make use of the half-bound carbon dioxide of bicarbonates, chiefly those of calcium and magnesium, dissolved in the water. Undoubtedly the kind and quantity of dissolved salts in lake waters is an important factor in controlling vegetative development. In Boulder Park lakes and ponds the absence of these salts is quite likely a most important factor limiting the growth of algae and other submerged aquatics.

The total absence of Scirpus, Typha, and Phragmites reed swamps in Boulder Park will be noted. 
Sphagnum Bogs.- Sphagnum moss is found in very small amounts here and there in the Park, but in no place is there any approach to the formation of sphagnum moor. Small sphagnum moors are occasionally found at higher elevations in heavily forested areas in northern Colorado, but never are they as well developed and characteristic as those found north and east in the United States.

For the optimum development of sphagnum, there must be abundant precipitation, slow evaporation from the surface, slow percolation and run-off of soil water, low temperature, and absence of drying winds. In only favored situations are such conditions found in Colorado. Boulder Park is a very unfavorable locality for the development of sphagnum moors. Here the drainage is generally good, the temperatures of both air and soil may run high, at least for a short period, many seasons are dry, and the winds are desiccating. In his description of the bog plant societies of northern North America, Transeau (24) has selected I 5 characteristic bog plants: Menyanthes trifoliata, Dulichium arundinaceum, Comarum palustre, Scheuchzeria palustris, Eriophorum polystachon, Drosera rotundifolia, Sarracenia purpurea, Oxycoccus oxycoccus, Chiogenes hispidula, Andromeda polifolia, Chamaedaphne calyculata, Ledum groenlandicum, Kalmia glauca, Betula pumila, and Larix laricina. Of these, Eriophorum polystachyon is the only one found in Boulder Park, and it is rare. Menyanthes trifoliata has been found in a bog a number of miles north of Boulder Park.

The writer is indebted to Dr. H. C. Cowles, under whom this study was conducted, for his helpful suggestions and criticisms; to Professor Francis Ramaley for valuable advice and for laboratory facilities granted at the Mountain Laboratory for Field Biology ('Tolland, Colorado); to Professor Aven Nelson, who identified a large number of the specimens; and to Mr. A. S. Hitchcock for the identification of some difficult species of $P o a$.

State Agricultural College

Fort Collins, Colo. 


\section{LITERATURE CITED}

I. Atwood, W. W., The glaciation of the Uinta Mountains. Jour. Geol. 15:790-804. I907.

2. Birge, E. A., and Juday, C., The inland lakes of Wisconsin; dissolved gases and their biological significance. Wis. Surv. Bull. 22. I9I I.

3. Bruderlin, Katherine, A study of the lodgepole pine forests of Boulder Park, Tolland, Colo. Univ. Colo. Studies 8:265-275. I9 I I.

4. Capps, S. R., and Leffingwell, E. D. K., Pleistocene geology of the Sawatch Range near Leadville, Colo. Jour. Geol. I2:698-706. I904.

5. Chambers, C. O., The relation of algae to dissolved oxygen and carbon dioxide with speciall reference to the carbonates. 23d Ann. Rep. Mo. Bot. Gard. I 7 I-207. I9I 2.

6. Fuller, G. D., A comparison of certain Rocky Mountain grasslands with the prairie of Illinois. Trans. Ill. Acad. Sci. 8: I-Io. I9I7.

7. Gwillim, J. C., Glaciation in the Atlin district, British Columbia. Jour. Geol. 10:I82-I86. I902.

8. Hershey, O. H., The relation between certain river terraces and the glacial series in Northwestern California. Jour. Geol. I I:43I-459. I903.

9. Jefferson, W. D., A certain type of lake formation in the Canadian Rocky Mountains. Jour. Geol. 7:247-26r. I899.

ro. Ramaley, Francis, Plant zones in the Rocky Mountains of Colorado. Science N.S. 26:642-643. I907.

I r. - Botanical opportunity in Colorado. Univ. Colo. Studies 6:5-10. I908.

12. - The University of Colorado Mountain Laboratory. Univ. Colo. Studies 7:9I-95. I909.

13. - Northern Colorado plant communities with special reference to Boulder Park. Univ. Colo. Studies 7:223-236. I9 Io.

I4. - The amount of bare ground in some mountain grasslands. Вот. GAZ. 57:526-528. I9I4.

15. — The relative importance of different species in a mountain grassland. Bот. GAz. 60: I54-I57. I9 I5.

r6. — Quadrat studies in a mountain grassland. Bот. GAz. 62:70-74. I9I6.

I7. - Dry grassland of a high mountain park in Northern Colorado. Plant World r9:249-270. I9r6.

r8. Ramaley, Francis, and Mitchell, L. A., Ecological cross-section of Boulder Park (Tolland, Colo.). Univ. Colo. Studies 8:277-287. I9I I.

19. Ramaley, Francis, and Robbins, W. W., A summer laboratory for mountain botany. Plant World I2: 105-I 10. I909.

20. — Studies in lake and streamside vegetation. I. Redrock Lake near Ward, Colo. Univ. Colo. Studies 6: I. I909. 
2I. ReED, E. L., Meadow vegetation in the montane region of Northern Colorado. Bull. Torr. Bot. Club 44:97-rog. I9 7 .

22. Robbins, W. W., Native vegetation and climate of Colorado in their relation to agriculture. Colo. Agric. Exper. Sta. Bull. 224:I-56. I9 7 .

23. Salisbury, R. D., and Blackwelder, F., Glaciation in the Bighorn Mountains. Jour. Geol. I I:2 I6-223. I903.

24. Transeau, E. N., On the geographical distribution and ecological relations of the bog plant societies of Northern America. Bot. Gaz. 36:40I-42I. I903.

25. Wesenberg-Lund, Comparison of Scottish with Danish lakes. Revue Hydrobiol. I : $184-187$. I908.

26. Westgate, L. H., The Twin Lakes glaciated area, Colorado. Jour. Geol. I3:285-3I 2. I 905 . 


